\title{
PKM PEMBUATAN RAK BESI UNTUK POT BUNGA DENGAN CARA PENGELASAN OLEH PEMUDA GMIM HIDUP BARU MAESA UNIMA KECAMATAN TONDANO SELATAN KAB. MINAHASA
}

\author{
Denny Darly Maukar \\ Universitas Negeri Manado \\ dennymaukar@unima.ac.id
}

\section{PENDAHULUAN}

\section{Analisis Situasi}

Badan Pusat Statistik (BPS) mencatat angka pengangguran di Indonesia. Tingkat pengangguran terbuka Indonesia hingga Februari 2017 sebesar 5,33 persen, Dari sisi jumlah angkatan pengangguran terbuka menurut pendidikian di dominasi oleh Sekolah Menengah Kejuruan (SMK) 12,65 \% di susul Sekolah Menengah Atas (SMA) 10,32 $\%$, Diploma 7,54 \%, Sarjana 6,40 \%, Sekolah menengah Pertama 6,22 \% dan Sekolah dasar Kebawah 2,74 \%. Hal ini sangat mencemaskan karena angka ini masih sangat besar pengangguran yang terjadi di awal tahun 2017 ini sangat berdapak pada kehidupan masyarakat.

Masih tingginya pengangguran di kalangan usia muda produktif semakin menunjukkan bahwa ketersediaan lapangan kerja yang sangat terbatas. Hal ini tentu saja disebabkan oleh banyak faktor yang sangat kompleks. Namun demikian, salah satu solusi yang sangat realistis untuk diwujudkan adalah melalui usaha peningkatan jumlah wirausaha terutama di kalangan muda produktif, yang dalam hal ini dapat diwakili oleh kelompok pemuda putus sekolah didesa di dusun-dusun atau minimal di tingkat kelurahan. Salah satu alternatif solusinya adalah melalui pemberdayaan generasi muda agar mampu berwirausaha melalui pelatihan keterampilan produksi komoditas yang dapat diterima pasar secara mudah. Sasaran antara yang strategis adalah kelompok Pemuda Gereja yang ada Desa/Kelurahan dan tingkat dusun.

Salah satu keterampilan yang mampu menghasilkan produk yang masih terbuka luas pemasarannya adalah bidang kerajinan las. Apalagi produk las yang memiliki nilai ilmiah, Karena itu konsep pemberdayaan sumber daya manusia, khususnya pemuda, dalam kegiatan ini dilandasi dengan kondisi eksisting di masyarakat, yang memerlukan upaya 
pemberdayaan dalam wacana pembangunan masyarakat dihubungkan dengan konsep mandiri, partisipasi, jaringan kerja dan keadilan. Dalam kegiatan Pengabdian Pada Masyarakat (PPM) ini, akan dilakukan pemberdayaan secara generik, yaitu dimulai dengan pola pencitraan menjadi kelompok produktif yang berguna dalam mendukung munculnya wirausaha baru yang kreatif, peningkatan kecakapan hidup (life skill), dan pola pemasaran yang bersifat kolaboratif dengan sekolah dalam mengembangkan media pembelajaran teknik pengelasan.

Bidang usaha produktif yang dipilih dalam kegiatan PPM ini adalah bidang las karena sangat potensial untuk langsung dijadikan wirausaha baru. Bidang kerajinan las adalah usaha yang masih sangat minim pesaing di Desa/Kelurahan.

Dalam kegiatan Pengabdian Pada Masyarakat (PPM) ini, akan dilakukan pelatihan secara intensif dalam kerajinan las, yaitu dimulai dengan penambahan ketermpilan yang berguna dalam mendukung munculnya wirausaha baru yang kreatif, peningkatan kecakapan hidup (life skill), dan pola pemasaran yang bersifat kolaboratif dengan memanfaatkan yang besar.

\section{B. SOLUSI DAN TARGET LUARAN}

Usaha teknik pengelasan saat ini mengalami perkembangan yang cukup signifikan. Pemasaran produk kerajinan las memerlukan keterampilan tersendiri. Pengelasan (welding) adalah salah satu teknik penyambungan besi dengan cara memperlihatkan kesesuaian antara sifat-sifat las dengan kegunaan kontruksi serta kegunaan disekitarnya. Prosedur pengelasan kelihatannya sangat sederhana, tetapi sebenarnya didalamnya banyak masalahmasalah yang harus diatasi dimana pemecahannya memerlukan bermacam-macam penngetahuan. Karena itu didalam pengelasan, penngetahuan harus turut serta mendampingi praktek, secara lebih terperinci dapat dikatakan bahwa perancangan kontruksi bangunan dan mesin dengan sambungan las, harus direncanakan pula tentang cara-cara pengelasan. Cara ini pemeriksaan, bahan las, dan jenis las yang akan digunakan, berdasarkan fungsi dari bagianbagian bangunan atau mesin yang dirancang. Berdasarkan definisi dari DIN (Deutch Industrie Normen) las

adalah ikatan metalurgi. Pada waktu ini telah dipergunakan lebih dari 40 jenis pengelasan 
klasifikasi dari cara-cara pengelasan ini akan diterangkan lebih lanjut. Pada waktu ini pengelasan dan pemotongan merupakan pengelasan pengerjaan yang amat penting dalam teknologi produksi dengan bahan baku besi.

Sampai pada waktu ini
banyak sekali cara-cara
pengklasifikasian yang digunakan
dalam bidang las, ini disebabkan
karena perlu adanya kesepakatan
dalam hal-hal tersebut. Secara
konvensional cara-cara
pengklasifikasi tersebut pada
waktu ini dapat dibagi dua
golongan, yaitu klasifikasi
berdasarkan kerja dan klasifikasi
berdasarkan energi yang
digunakan. Klasifikasi pertama
membagi las dalam kelompok las
cair, las tekan, las patri dan lain-
lainnya. Sedangkan klasifikasi yang
kedua membedakan adanya
kelompok-kelompok seperti las
listrik, las kimia, las mekanik dan
seterusnya. Bila diadakan
pengklasifikasian yang lebih
terperinci lagi, maka kedua
klasifikasi tersebut diatas dibaur
dan akan terbentuk kelompok-
kelompok yang banyak sekali.

Diantara kedua cara klasifikasi tersebut diatas kelihatannya klasifikasi cara kerja lebih banyak digunakan

karena itu pengklasifikasian yang diterangkan dalam bab ini juga berdasarkan cara kerja. Berdasrkan klasifikasi ini pengelasan dapat dibagi dalam tiga kelas utama yaitu pengelasan cair, pengelasan tekan dan pematrian.

a. Pengelasan cair adalah cara pengelasan dimana sambungan dipanaskan sampai mencair dengan sumber panas dari busur listrik atau sumber api gas yang terbakar.

b. pengelasan tekan adalah pcara pengelasan dimana sambungan dipanaskan dan kemudian ditekan hingga menjadi satu.

c. pematrian adalah cara pengelasan diman sambungan diikat dan disatukan

Las busur listrik atau pada umumnya disebut termasuk suatu proses penyambungan dengan menggunakan tenaga listrik sebagai sumber panas. Jadi surnber panas pada ditimbulkan oleh busur api arus listrik, antara elektroda las dan benda kerja. Benda kerja merupakan bagian dari rangkaian aliran arus listrik las. 
Elektroda mencair bersama-sama dengan benda kerja akibat dari busur api arus listriik. Gerakan busur api diatur sedemikian rupa, sehingga benda kerja dan elektroda yang mencair, setelah dingin dapat menjadi satu bagian yang sukar dipisahkan.

Busur listrik yang terjadi di antara ujung elektroda dan bahan dasar akan mencairkan ujung elektroda dan sebagaian bahan dasar. Selaput elektroda yang turut terbakar akan mencair dan menghasilkan gas yang melindungi ujung elekroda kawah las, busur listrik terhadap pengaruh udara luar. Cairan selaput elektroda yang membeku akan memutupi permukaan las yang juga berfungsi sebagai pelindung terhadap pengaruh luar. Perbedaan suhu busur listrik tergantung pada tempat titik pengukuran, missal pada ujung elektroda bersuhu $3400^{\circ} \mathrm{C}$, tetapi pada benda kerja dapat mencapai suhu $4000^{\circ} \mathrm{C}$.

TIG (Tungsten Inert Gas = Tungsten Gas Mulia) menggunakan elektroda wolfram yang bukan merupakan bahan tambah. Busur listrik yang terjadi antara ujung elektroda wolfram dan bahan dasar merupakan sumber panas, untuk pengelasan. Titik cair elektroda wolfram sedemikian tingginya sampai $3410^{\circ} \mathrm{C}$, sehingga tidak ikut mencair pada saat terjadi busur listrik. Tangkai listrik dilengkapi dengan nosel keramik untuk penyembur gas pelindung yang melindungi daerah las dari luar pada saat pengelasan.
Sebagian bahan tambah dipakai elektroda tampa selaput yang digerakkan dan didekatkan ke busur yang terjadi antara elektroda wolfram dengan bahan dasar. Sebagi gas pelindung dipakai argin, helium atau campuran dari kedua gas tersebut yang pemakainnya tergantung dari jenis yang akan dilas. Tangkai las TIG biasanya didinginkan dengn air yang bersirkulasi.

Seperti halnya pad a TIG, pad a MIG juga panas ditimbulkan oleh busur listrik antara dua electron dan bahan dasar. Elektroda merupakan gulungan kawat yang berbentuk rol yang geraknya diatur oleh pasangan roda gigi yang digerakkan oleh motor listrik. Gerakan dapat diatur sesuai dengan keperluan. Tangkai las dilengkapi dengan nosel Kaca untuk menghubungkan gas pelindung yang dialirkan dari botol gas melalui slang gas. Gas yang dipakai adalah CO2 untuk pengelasan baja lunak dan baja. Argon atau campuran argon dan helium untuk pengelasan aluminium dan baja tahan karat. Proses pengelasan MIG ini dadpat secara semi otomatik atau otomatik. Semi otomatik dimaksudkan pengelasan secara manual, sedangkan otomatik adalah pengelasan yang seluruhnya dilaksanakan secara otomatik. Elektroda keluar melalui tangkai bersama-sama dengan gas pelindung. 
Tahapan Pelaksanaan Kegiatan dan Pendampingan

Tabel 3. Tahapan Pelaksanaan Kegiatan dan pendampingan

\begin{tabular}{|c|c|c|c|}
\hline No & Jenis Kegiatan & \begin{tabular}{|l|} 
Bukti \\
Dokumen
\end{tabular} & $\begin{array}{l}\text { Waktu } \\
\text { pelaksanaan }\end{array}$ \\
\hline 1 & $\begin{array}{l}\text { Koordinasi, dan memfasilitasi pemuda gerja } \\
\text { untuk melaksanakan produksi kerajinan } \\
\text { berbasis teknik las }\end{array}$ & \begin{tabular}{|l|} 
Surat \\
kesediaan \\
kerjasama
\end{tabular} & Maret 2019 \\
\hline 2 & $\begin{array}{l}\text { Produksi dan pendampingan penguasaan } \\
\text { Teknik las }\end{array}$ & $\begin{array}{l}\text { Daftar hadir } \\
\text { dan foto } \\
\text { kegiatan }\end{array}$ & $\begin{array}{l}\text { Maret - April } \\
2019\end{array}$ \\
\hline 3 & $\begin{array}{l}\text { Produksi dan pendampingan penguasaan } \\
\text { Teknik las }\end{array}$ & $\begin{array}{l}\text { Data dan foto } \\
\text { kegiatan }\end{array}$ & 2019 \\
\hline 4 & $\begin{array}{l}\text { Produksi dan pendampingan Pembuatan } \\
\text { kerajinan las }\end{array}$ & $\begin{array}{l}\text { Data dan foto } \\
\text { kegiatan }\end{array}$ & $\begin{array}{l}\text { juni } \\
2019\end{array}$ \\
\hline 5 & $\begin{array}{l}\text { Produksi dan pendampingan Pembuatan } \\
\text { kerajinan las }\end{array}$ & \begin{tabular}{|l|} 
Data \\
Foto kegiatan \\
\end{tabular} & $\begin{array}{l}\text { Juni } \\
2019 \\
\end{array}$ \\
\hline 6 & $\begin{array}{l}\text { Produksi dan pendampingan pengembangan } \\
\text { Kerajinan las }\end{array}$ & $\begin{array}{l}\text { Data } \\
\text { Foto kegiatan }\end{array}$ & $\begin{array}{r}\text { Juni } \\
2019 \\
\end{array}$ \\
\hline 7 & $\begin{array}{l}\text { Produksi dan pendampingan pengembangan } \\
\text { pemasaran kerajinan las }\end{array}$ & $\begin{array}{l}\text { Data } \\
\text { Foto kegiatan }\end{array}$ & $\begin{array}{l}\text { Juni } \\
2019\end{array}$ \\
\hline 8 & $\begin{array}{l}\text { Produksi dan pendampingan; Insentif } \\
\text { pembentukan kelompok usaha }\end{array}$ & $\begin{array}{l}\text { Data } \\
\text { Foto kegiatan }\end{array}$ & $\begin{array}{l}\text { Juni - Juli } \\
2019 \\
\end{array}$ \\
\hline
\end{tabular}

Sebagaimana telah diuraikan pada bagian metode pelaksanaan kegiatan maka evaluasi dilakukan pada setiap tahapan kegiatan dengan menggunakan berbagai instrumen, diantaranya; Lembar observasi pelaksanaan kegiatan, Angket respon peserta pelatihan, Lembar penilaian kinerja, pendampingan dan analisis produk dan pemasarannya dengan menggunakan data primer

\section{KELAYAKAN PERGURUAN TINGGI}

Pelaksanaan kegiatan pelatihan ini merupakan salah satu bentuk perwujudan dari Tri Dharma Perguruan Tinggi yaitu melaksanakan pengabdian kepada masyarakat. Pelaksanaan pengabdian pada masyarakat untuk Unima berada di bawah tugas dan kewenangan dari Lembaga Pengabdian Kepada Masyarakat (LPM) Unima. Dalam beberapa tahun terakhir LPM Unima selalu aktif dalam memberikan informasi kepada semua dosen yang ada di lingkungan Unima mengenai adanya usulan kegiatan pengabdian pada masyarakat bagi pendanaan yang bersumber BOPTN Unima maupun yang dibiayai oleh Dikti. Sesuai standar evaluasi DRPM Dikti, maka kegiatan pengabdian yang dibiayai oleh Unima akan diperiksa oleh reviewer eksternal yang berkompeten dan profesional dalam melaksanakan kegiatan pengabdian pada masyarakat.

Keahlian di bidang teknologi pengelasan sangat diperlukan dalam menyelesaikan masalah yang dihadapi mitra. Tim yang terlibat dalam pelaksana kegiatan ini memiliki kompetensi dalam bidang pengembangan dan penerapan teknologi pengelasana sehingga sangat relevan dengan kegiatan ini. Tim pelaksana merupakan dosen tetap Fakultas Teknik Unima.

Pengusul dan pelaksana kegiatan Ipteks bagi masyarakat ini terdiri dari satu orang dosen dan dua orang mahasiswa dari Program Studi Pendidikan Teknik Mesin Fakultas Teknik Universitas Negeri Manado. Sebagai ketua tim yaitu Drs Denny Darly Maukar, M.Eng. Bidang keahlian dari ketua adalah teknik mesin. Ketua pelaksana menjadi pengampu mata kuliah Teknologi Mekanik

\section{HASIL DAN LUARAN YANG DICAPAI}

Kegiatan PPM yang berjudul Pembuatan Tenda Dengan cara Pengelasan Oleh Pemuda gereja GMIM Hidup Baru 
Maesa Unima Kecamatan Tondano Selatan Kabupaten Minahasa ini ditujukan untuk meningkatkan keterampilan kalangan muda usia produktif dalam memproduksi produk kerajinan las melalui pelatihan dan pendampingan yang melibatkan Pemuda gereja yang putus sekolah

mulai dari tahapan desain, pembuatan, dan pemasaran. Kegiatan ini diiringi dengan pemberdayaan kolaboratif dengan membangun system kelembagaan yang baik bagi kelompok muda usia produktif dalam pengembangan wirausaha muda mandiri. Indikator capaian produk Program PPM yang dituju dalam kegiatan ini adalah:

1. Peningkatan keterampilan kelompok pemuda usia produktif, khususnya mereka yang menganggur, dalam memproduksi produk kerajinan las melalui pelatihan las yang ditunjukkan dengan kualitas produk dan penerimaan oleh konsumen.

2. Terbentuknya kelompok usaha dalam bidang las yang mampu menjadi sentra produksi kerajinan yang dapat diterima oleh masyarakat

3. Tersedianya sistem pemberdayaan kolaboratif sehingga dapat digunakan dalam mengembangkan kerjasama yang lebih intensif antara pemuda gereja dan perguruan Tinggi dan institusi non formal di masyarakat.
4. Meningkatkan persepsi kalangan muda usia produktif agar memiliki pencitraan yang lebih positif dan berharga terhadap kewirausahaan.

5. Membangun kemitraan dan kerjasama yang efektif antara pemuda gereja dan perguruanTinggi,

Sosialisasi rancangan metode ini dilakukan bersamaan dengan kegiatan diskusi. Pada sosialisasi ini dijelaskan kelebihan dan keuntungan penggunaan Las untuk peningkatan keterampilan pemuda gereja. Penjelasan juga mencakup bahan-bahan yang digunakan serta mekanisme penggunaannya. Disamping itu dilakukan pula identifikasi potensi pemuda gereja yang diharapkan dapat lebih berkembang sehingga memungkinkan pengembangan yang berkelanjutan. menjelaskan materi dasar tentang penggunaan Las untuk peningkatan keterampilan pemuda gereja.

Pelatihan pemanfaatan Las untuk peningkatan keterampilan pemuda gereja. Kegiatan pelatihan 2 orang mahasiswa dan satu orang dosen pengabdi. Materi yang dilatihkan mencakup tinjauan teori las dan Praktek Implementasi.

Hasil yang dicapai pada kegiatan ini adalah sampai pada tahapan pemuda gereja mampu menggunakan Las untuk peningkatan keterampilan dalam bentuk praktek dan diskusi. Dari diskusi yang dilakukan pemuda gereja begitu antusias dengan kegiatan yang dilakukan (dapat 
dilihat dari angket tentang respon pemuda gereja dalam pelatihan) dan menganggap bahwa kegiatan pelatihan ini sangat penting dalam memperkaya pengetahuan dan pemahaman mereka tentang teknologi Las untuk peningkatan keterampilan membuat alat.

Proses pelatihan berlangsung penuh dinamika yang ditandai dengan tanya jawab anatara pelatih dan para pemuda gereja dalam suasana santai. Banyak diantara mereka yang aktif membuat mencoba sendiri dan hanya sebagian kecil saja yang ragu-ragu dan hanya membantu teman lainnya yang bekerja. Hasil yang didapat kemudian diujicobakan dikalangan mereka sendiri dan ternyata hasilnya baik

\section{KESIMPULAN DAN SARAN}

Salah satu alternatif solusinya adalah melalui pemberdayaan generasi muda agar mampu berwirausaha melalui pelatihan keterampilan produksi komoditas yang dapat diterima pasar secara mudah. Sasaran antara yang strategis adalah kelompok Pemuda gereja yang ada di kelurahan/desa dan tingkat dusun, Salah satu keterampilan yang mampu menghasilkan produk yang masih terbuka luas pemasarannya adalah bidang kerajinan las Berdasarkan rasional ini maka tujuan umum PPM ini adalah menghasilkan wirausaha kerajinan las melalui pemberdayaan kelompok pemuda usia produktif melalui pelatihan keterampilan las, Tujuan khususnya adalah;
(1) meningkatkan keterampilan kelompok pemuda produktif di kelurahan/ desa sebagai sasaran antara yang strategis dalam mendesain produk dan keterampilan las melalui kegiatan workshop dan pendampingan, (2) melibatkan mahasiswa dalam peningkatan keterampilan pemuda gereja sebagai sasaran utama yang strategis dalam mengembangkan wirausaha kerajinan las, (3) membangun jaringan kerja dalam bentuk kelompok produksi usaha kecil dan membuka akses pemasaran melalui kemitraan antara pemuda desa dan perguruan tinggi, (4) mengembangkan pola pemberdayaan kolaboratif melalui pendampingan dalam transfer keterampilan, modal dan akses pemasaran yang lebih luas. Metode yang digunakan dalam pemberdayaan didasarkan pada kelayakan usaha, ketersediaan produk kerajinan las, nilai ekonomi produk, ketersediaan SDM pengelola, teknologi, aspek financial dan dampak sosialnya.

Proses pelatihan berlangsung penuh dinamika yang ditandai dengan tanya jawab anatara pelatih dan para pemuda gereja dalam suasana santai. Banyak diantara mereka yang aktif membuat mencoba sendiri dan hanya sebagian kecil saja yang ragu-ragu dan hanya membantu teman lainnya yang bekerja. Hasil yang didapat kemudian diujicobakan dikalangan mereka sendiri dan ternyata hasilnya baik dan layak untuk digunakan dalam pembelajaran las 
Prosentase aktivitas tim pengabdi dan aktivitas pemuda gereja yang terjadi selama proses pelatihan. Prosentase aktivitas tim pengabdi berkisar antara 8.5\% sampai $36.8 \%$. Aktivitas tim yang paling dominan adalah menjelaskan materi pelatihan, yaitu $45.5 \%$ dan mengusahakan contoh tambahan $11.5 \%$. sedangkan aktivitas yang paling sedikit adalah memberikan umpan balik $8 \%$ dan merangsang untuk terlibat aktif $8.5 \%$.

Sedangkan aktivitas pemuda gereja didominasi oleh kegiatan Mendengarkan/ memperhatikan penjelasan tim pelatih atau pemuda gereja yang lain $35.2 \%$ dan yang paling sedikit adalah mengajukan pertanyaan $12.4 \%$ dan menuliskan hal yang penting $14.4 \%$.

\section{KEPUSTAKAAN}

Delavand Ovono Ovono, Giovanni Bruno, Philippe Pradeau, and Stephane Berre.
(2013). Conditions for Crystallization of LAS Glass-Ceramics as a Function of Nucleating Agent Amount and Heat Treatment. International Journal of Applied Glass ScienceVolume 4, Issue 1 , pages 20-30, March 2013

Joos van Kasteren (2006) Artikel Cara

$\begin{array}{lrr}\text { Mengelas } & \text { Tambah } & \text { Canggih } \\ \text { (terjemahan), } \quad \text { Majalah } & \text { Sigma } \\ \text { Kaleidoskop Dunia Ilmu, Edisi } 11 \\ \text { Tahun 1986. }\end{array}$

Howard B. Cary (1998) Modern Welding Technology, 4th edition. Published by Prentice-Hall

http://theshaset.blogspot.com/2011/05/tri k-pengelasan.html

Liu Zhien, Yuan Jianjun, Xue Zhiyun (2005). The interface, microstructure and mechanical properties of Cf/LAS glassceramic composites. Journal of Materials Science 15 January 2005, Volume 30, Issue 2, pp 399-404 